\title{
Modeling and Optimization of Struvite Crystal Scaling Using Experimental Design Methodology For Maleic Acid
}

\author{
D. S. Perwitasari ${ }^{1}$ \\ Department of Chemical Engineering \\ Universitas Pembangunan Nasional "Veteran" Jawa Timur \\ Surabaya, Indonesia \\ 1'saridyah05@gmail.com
}

\author{
A.P. Bayuseno ${ }^{2}$, J.Jamari \\ Mechanical Enginering Graduate Program \\ Diponegoro University \\ Semarang, Indonesia \\ 2apbayuseno@gmail.com
}

\author{
S. Muryanto \\ Department of Chemical Engineering \\ Universitas Tujuh Belas Agustus \\ Semarang, Indonesia
}

\begin{abstract}
This paper presents results of an investigation of scaling of magnesium ammonium phosphate hexahydrate (struvite) on a process batch crystallizer. In this study, variables, namely temperature $\left(30-40^{\circ} \mathrm{C}\right)$, stirring speed $(200-400 \mathrm{rpm})$, maleic acid concentration (1-20 ppm) were optimized using RSM (response surface methodology) to provide the optimum yield of the mass scales. The RSM prediction provided that the maleic acid concentration was the most significant factor for scale yield, while the temperature and the stirring speed were insignificant factors determining the optimal condition of the mass scale yields. The optimum mass scale response of $10.43 \mathrm{mg}$ was obtained at a temperature of $30{ }^{\circ} \mathrm{C}$, stirring speed of $300 \mathrm{rpm}$ and maleic acid concentration of $20 \mathrm{ppm}$, respectively. This gave the best combination of process parameters for struvite crystallization in an aqueous solution.
\end{abstract}

Keywords - Response surface methodology (RSM), Struvite crystallization, XRPD Rietveld analysis

\section{INTRODUCTION}

Struvite is a common mineral deposit found in pipes, pumps and other industrial equipment [1,2]. Precipitation of struvites may interfere with equipment performance and lead to increased maintenance costs. However, struvite precipitation is now considered a prospective technology for phosphate recovery from wastewater treatment, municipal waste, industrial waste and liquid fertilizer [3,4]. Lately the sediment of struvite is attractive [4], because the final product has a potential market for the fertilizer industry. This can be achieved only by controlling the properties of the crystalline product, reflecting the composition of nitrogen $(\mathrm{N})$, phosphor (P) and magnesium $(\mathrm{Mg})$ ions in the same molar concentration [5]. While the purity and size of the crystal product can be obtained from the precipitation process by controlling the parameters and in designing the equipment [6]. Indeed for struvite precipitation, the nature and quantity of the final product in shape has been of considerable concern to all crystal products in order to be economically viable. As a result, the purity and size of the crystals have been handled for reuse as fertilizer, while the granules formed must be strong enough. Purity is sometimes in control for environmental reasons. An economic return of this crystallization process has been previously reported for the struvite production in the wastewater. [7]. Phosphorus (P) is one of the main chemical elements on earth but does not exist in the form of simple compound[s. This is combined with other elements (oxygen, hydrogen) to form phosphates. Although phosphorus (P) is essential for all living organisms, it is closely related to eutrophication. The eutrophication phenomenon comprises surface water nutrient enrichment, which causes an increase in excessive vegetation such as algae, which alters green water in reservoirs, rivers, coastal waters and the marine environment in general [8].

Phosphate is the main source of $\mathrm{P}$ commonly used as fertilizer, detergent or insecticide. Traditional $\mathrm{P}$ reduction processes with phosphorus fixation on mud activation either with biological approach (biological nutrient removal) or chemical (metal salt deposition). This process is efficient in the sense that they can reduce $\mathrm{P}$ concentration in liquid waste to approximately $1 \mathrm{mg} / \mathrm{L}$ [5], but causes nutrient accumulation $(\mathrm{P}, \mathrm{N})$ in the sludge and contributes to the reaction of magnesium and ammonium ions resulting in struvite deposits as a crystalline crust affecting the efficiency of the treatment process, including dilution of sruvite crystals in waste water [9] , preventive measures with iron salt [10] or addition of chemical inhibitors [4,6]. To reduce the struvite deposits as crystalline crusts generally use inorganic additives [11,12], [13] or organic additives [14], [15].

There are several key requirements that are effective as additives are: 1. Available easily. 2. Effective at low concentrations. 3. Cheap and significantly will not affect the cost of production. 4. Ideal and non-toxic to the environment. 
5. Reduce mineral formation or prevent nucleation. Carboxylic acids as additives meet many of the above requirements [15]. However, many studies to date have not focused on the characteristics of similarities and differences. Efforts to understand the long-term process of mineral stability involved in complex, homogeneous, chemical equilibrium systems require qualitative and quantitative qualitative mineralization of the precipitate. In addition, quantitative mineralogical characterization is required for efficient quality control in a variety of crystalline morphology and struvite purity. These results also provide important insights for crystal growth on natural conditions and within the laboratory. Therefore, this study is needed to better understand how maleic acid as an additive can affect the nucleation and growth of struvite crystals and observe the impact on the quality of struvite products as a fertilizer.

The present study was undertaken of an investigation of scaling of magnesium ammonium phosphate hexahydrate (struvite) on a process batch crystallizer. The variables investigated were temperature, stirring speed, maleic acid concentration were optimized using RSM (response surface methodology) to provide the optimum yield of the mass scales. The crystalline solid product was then characterized using XRPD method for mineral composition.

\section{MATERIALS AND METHOD}

\section{A. Preparation of Crystal-Forming Solution}

The supersaturated solutions for the experiments were prepared mainly containing $\mathrm{MgCl}_{2} \cdot 6 \mathrm{H}_{2} \mathrm{O}$ and $\mathrm{NH}_{4} \mathrm{H}_{2} \mathrm{PO}_{4}$ with analytical grade chemicals (Merck ${ }^{\mathrm{TM}}$ ), without further purification. In this way, both powder crystals were separately dissolved in a double-distilled water to provide the equimolar of $0.30 \mathrm{M}$ for each ion $\mathrm{Mg}^{2+}, \mathrm{NH}^{4+}$ and $\mathrm{PO}_{4}^{-3}$. The $\mathrm{pH}$ of both solutions was adjusted to 9 by adding $0,5 \mathrm{~N} \mathrm{KOH}$ solution. The effect of temperature $\left(30^{\circ} \mathrm{C}, 35^{\circ} \mathrm{C}, 40^{\circ} \mathrm{C}\right)$, stirring speed $(200$, $300,400 \mathrm{rpm})$, maleic acid concentration $(1,10,20 \mathrm{ppm})$ Was evaluated in this work. In this case, crystals citric acid were dilute and added into $\mathrm{MgCl}_{2}$ solution. The precipitation process was monitored by reducing the $\mathrm{pH}$ solution [11]. The mass of dried precipitate was weighed using Sartorius weigh-scale.

\section{B. Materials Characterization.}

Scanning electron microscopy (SEM) (JEOL JSM 5200) and energy dispersive X-ray spectroscopy (EDX) were used to examine the precipitate crystals struvite. In this way, the dried precipitates with different particle sizes below $100 \mu \mathrm{m}$ were previously embedded in epoxy on an Al-sample holder and sputtered with carbon for SEM/EDX analysis.

Phase identification of the precipitate was conducted by $\mathrm{X}$ ray powder difraction (XRPD) (Philips 1830/40) measurement. The scan parameters $\left(5-85^{\circ} 2 \theta, 0.020\right.$ steps, $\left.15 \mathrm{~s} / \mathrm{step}\right)$ were set-up for recording XRPD data of the sample. A PC-based search- match program (Philips X'Pert Plus) was initially employed for identifying candidate crystalline phases, which was subsequently verified by the Rietveld method available in the program [16]. The obtained values of the cell parameters and the calculated (wt. \%) levels of mineralogical phases were calculated by the program.

\section{Experimental Design and Optimization of Parameters}

In this present study, the input variables temperature, stirring speed, maleic acid concentration and the yield response of the optimum mass (mg) was performed by SRM given in Table 1. A multiple regression data analysis was conducted by the statistical v.6 software packages (StatSoft, Tulsa, OK, USA). Using this method, the proper response value and mathematical model fitted to the measured data was acquired from the experiments, and the independent variables of optimal conditions.

TABLE I. RANGE AND LEVEL OF INDEPENDENT VARIABLES.

\begin{tabular}{|l|l|c|c|}
\hline \multicolumn{1}{|c|}{ Independent variables } & $\begin{array}{c}\text { Low } \\
\text { Level }(-1)\end{array}$ & $\begin{array}{c}\text { Range and } \\
\text { Level } \\
\text { Center } \\
\text { Level }(\mathbf{0})\end{array}$ & $\begin{array}{c}\text { High } \\
\text { Level } \\
(+1)\end{array}$ \\
\hline Temperature $\left({ }^{0} \mathrm{C}\right)$ & 30 & 35 & 40 \\
\hline Stirring speed (rpm) & 200 & 300 & 400 \\
\hline $\begin{array}{l}\text { Maleic acid Concentration } \\
\text { (ppm) }\end{array}$ & 1 & 10 & 20 \\
\hline
\end{tabular}

\section{RESUlT AND DISCUSSION}

\section{A. Properties of Solid Precipitated Crystals}

The corresponding solids were then subjected to XRPD Rietveld method. The crystals are primarily composed of struvite. Upon the quantitative Rietveld analyses, struvite was precipitated in the wastewater streams as the major mineral. Shows the SEM image of the crystals obtained exhibiting aggregate formations of irregular prismatic-like crystalline of struvite. This formation was also confirmed again by EDX analysis, showing the chemical elements of $\mathrm{Mg}, \mathrm{O}$, and $\mathrm{P}$ corresponds to struvite composition.

\section{B. Predicted Model and Statistical Analysis}

Model of response variables was optimized using SRM with the input data (Table 1), which consisted of 3 factorial design $2^{(3)}$ providing $\mathrm{nc}=8 ; \mathrm{ns}=6 ;$ no $=2$ and run $=16$. Accordingly the concentration range of temperature $\left(\mathrm{X}_{1}, 30-40\right.$ $\left.{ }^{0} \mathrm{C}\right)$, Stirring speed $\left(\mathrm{X}_{2}, 200-400 \mathrm{ppm}\right)$ and maleic acid Concentration $\left(\mathrm{X}_{3}, 1-20 \mathrm{ppm}\right)$ was selected for the calculation. Factors and their levels for SRM consisted of low level $(-1)=$ $30,200,1$ high level $(+1)=40,400,20$, and the center point $(0)=$ $35,300,10$. The whole design of yield response of mass precipitate $(\mathrm{mg})$ is presented in Table 2.

Based on multiple regression analysis of the experimental data, the optimization resulted in the following second-order polynomial equation in term of code values:

$$
\begin{aligned}
Y=38.9597 & -1.19723 \times 1+0.01652 \times 12-0.1216 \times 2 \\
& -0.00213 \times 22-0.04191 \times 3+0.00006 \times 32 \\
& +0.00087 \times 1 \times 2+0.00036 \times 1 \times 3 \\
& -0.00013 \times 2 \times 3
\end{aligned}
$$


Where $\mathrm{Y}$ is the yield of mass scale $(\mathrm{mg})$, and $\mathrm{X}_{1}, \mathrm{X}_{2}$ and $\mathrm{X}_{3}$ are the coded variables for temperature, maleic acid concentration and stirring speed, respectively. Analysis of variance (ANOVA) was performed for determining significance of the model given in Table 3. The function of more significant variables obviously fits with the quadratic polynomial model of mass scale yield. The influence of the significance of a factor can be seen from F-value and p-value. The quadratic regression model showed the value of determination coefficient $\left(\mathrm{R}^{2}\right)$ of 0.964 with no significant lack of fit at $\mathrm{p}>0.05$ which means that the calculated model fitted $95 \%$ of the result and only $3.5 \%$ of the total variation did not fit to the model. The significance of the model was also judget by $F$-test, where $F$-value is defined as the ratio between MSF (mean squares of factor) of the MSE (mean squares of error). A factor can be said to have a significant effect when the $F$-value is greater than $F$-table.

TABLE II. DESIGN OF EXPERIMENTS WITH INDEPENDENT VARIABLES.

\begin{tabular}{|l|c|l|c|l|l|l|}
\hline \multicolumn{1}{|c|}{ Source } & $\begin{array}{c}\text { Sum of } \\
\text { squares } \\
(\text { SS })\end{array}$ & $\begin{array}{c}\text { Degree of } \\
\text { freedom } \\
(\text { DF })\end{array}$ & $\begin{array}{c}\text { Mean } \\
\text { Square } \\
(\text { MS })\end{array}$ & F-value & $\begin{array}{c}\text { F- } \\
\text { table }\end{array}$ & $\boldsymbol{R}^{2}$ \\
\hline S.S. & 17.523 & 9 & 17.523 & 96.280 & 4.1 & 0.964 \\
Regression & 1.091 & 6 & 0.182 & & & \\
S.S. Error & 18.614 & 15 & & & & \\
S.S. Total & & 15 & & & \\
\hline
\end{tabular}

TABLE III. ANOVA ANALYSES OF THE YIELD RESPONSE OF CRYSTALLINE MASS.

\begin{tabular}{|l|l|l|l|l|}
\hline Run & $\begin{array}{c}\text { Temperature } \\
\left.{ }^{0} \boldsymbol{C}\right)\end{array}$ & $\begin{array}{c}\text { Independent } \\
\text { variables } \\
\text { Maleic acid } \\
\text { Concentration } \\
(\text { ppm })\end{array}$ & $\begin{array}{c}\text { Stirring speed } \\
(\text { rpm })\end{array}$ & $\begin{array}{c}\text { Responses } \\
\text { mass scale } \\
(\boldsymbol{m g})\end{array}$ \\
\hline 1 & 30.00 & 1.00 & 200.00 & 12.55 \\
2 & 30.00 & 1.00 & 400.00 & 13.44 \\
3 & 30.00 & 20.00 & 200.00 & 11.32 \\
4 & 30.00 & 20.00 & 400.00 & 11.13 \\
5 & 40.00 & 1.00 & 200.00 & 12.97 \\
6 & 40.00 & 1.00 & 400.00 & 14.00 \\
7 & 40.00 & 20.00 & 200.00 & 11.35 \\
8 & 40.00 & 20.00 & 400.00 & 12.46 \\
9 & 26.59 & 10.00 & 300.00 & 11.05 \\
10 & 43.41 & 10.00 & 300.00 & 13.75 \\
11 & 35.00 & -5.98 & 300.00 & 13.59 \\
12 & 35.00 & 25.98 & 300.00 & 10.96 \\
13 & 35.00 & 10.00 & 131.82 & 12.92 \\
14 & 35.00 & 10.00 & 468.18 & 13.73 \\
15 & 35.00 & 10.00 & 300.00 & 11.42 \\
16 & 35.00 & 10.00 & 300.00 & 11.42 \\
\hline
\end{tabular}

The experimental results were analyzed in chart Pareto (Figure 1). Upon the analysis, p-value less than 0.05 is considered to have an insignificant effect contributed to the response. On the basis of the results given in Figure 1, it can be seen that maleic acid Concentration (X2) has major linear (L) effect for controlling struvite production, followed by Temperature (L) (X1) and stirring speed (X3); and their quadratic effects (Q) for stirring speed (X3)2; Temperature (X1)2 and maleic acid Concentration (X2)2. However, the quadratic effect of maleic acid Concentration (X2)2 can be ignored because they provide insignificance on the yield response of the mass scales.

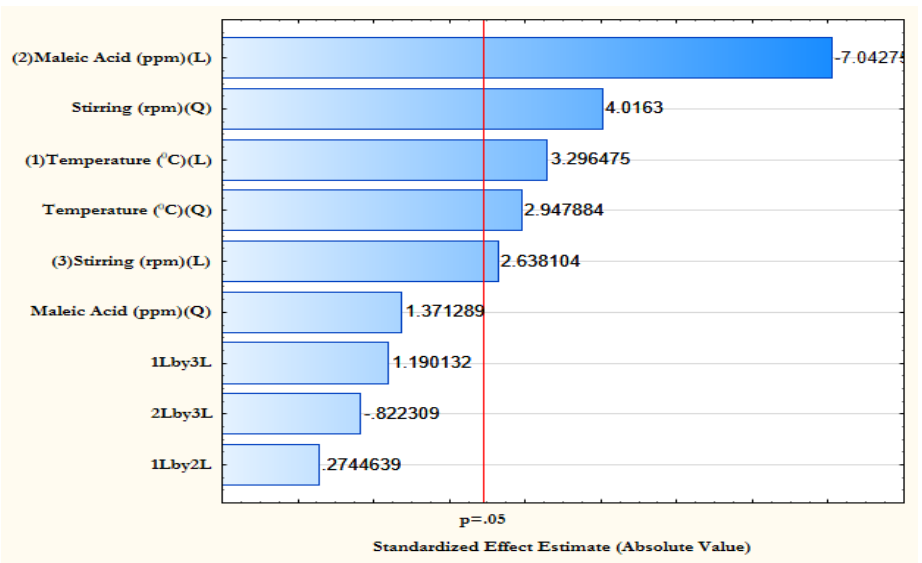

Fig. 1. Pareto Chart of Optimization Independent Variables on The Yield Response of Struvite Production. (L) Is The Linear and (Q) Is The Quadratic Interaction of Variables.

\section{Optimization of Independent Variables for the Optimum Struvite Production}

The graphical results of interactive independent and dependent variables are depicted by $3 \mathrm{D}$ and $2 \mathrm{D}$ contour plots, which enable to determine the optimum recovery of struvite (mass in mg) (Figs. 2-4). Different forms of the contour plots indicate the different interactive effects, where the significant interactions between the variables is shown in an elliptical contour plot. In contrast, a circular contour plot shows the insignificant interactive effects.

Figure 2 presents the interaction between temperature and maleic acid concentration for the yield of struvite. As expected, the yield of struvite increases when the highest temperature is applied. However, the presence of increased maleic acid concentration led to the reduced production of struvite.

Figure 3 presents the interaction between maleic acid concentration and stirring speed and the yield of struvite. When the stirring speed increase the high amount of struvite could be produced, while the increasing maleic acid concentration show the reduced production of struvite. Both temperature and stirring speed have significant effects on the struvite production.

Figure 4 presents the interaction between temperature and stirring speed on the yield of mass scale. Apparently, the increase of temperature from 30 to $35{ }^{\circ} \mathrm{C}$ makes a decrease in the struvite production. Similarly, the increase of stirring speed from 200 to $300{ }^{\circ} \mathrm{C}$ in the decrease of struvite production. 

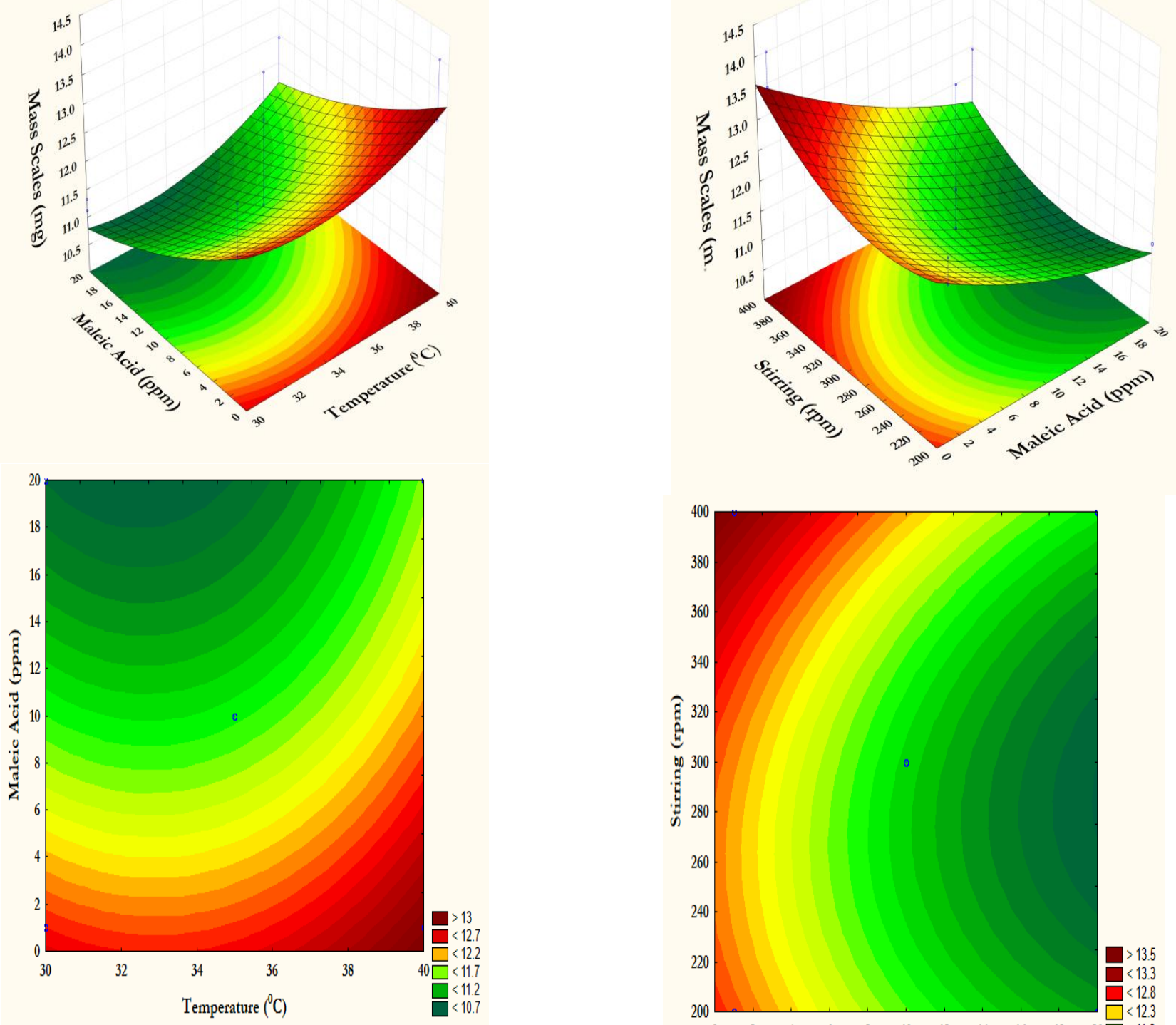

Fig. 2. Response Surface Contour for Mass Crystal Production Between Temperature and Maleic Acid Concentration.

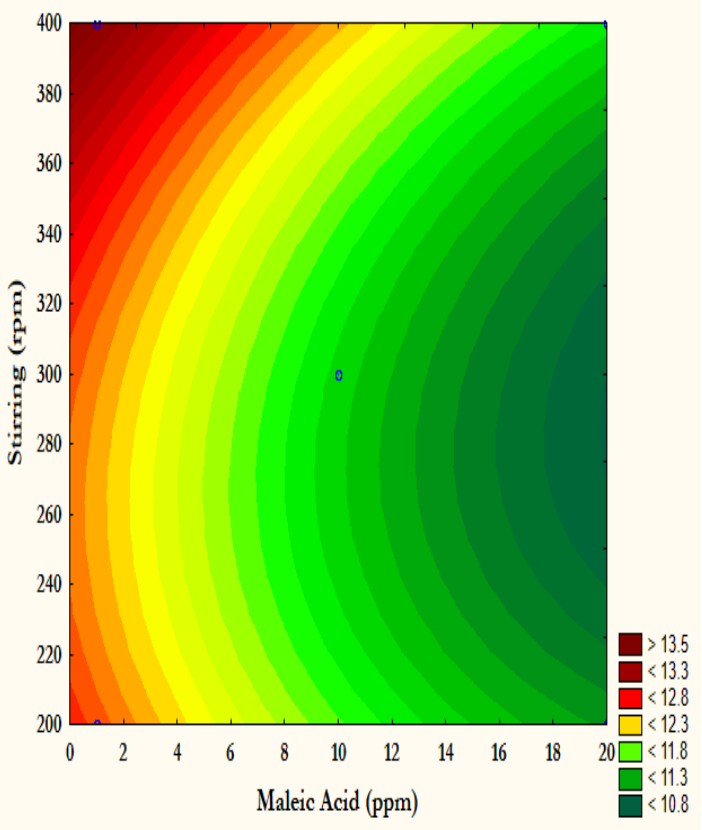

Fig. 3. Response Surface and Contour Plot for Interaction on Mass Crystal Production Between Maleic Acid Concentration and Stirring Speed. 

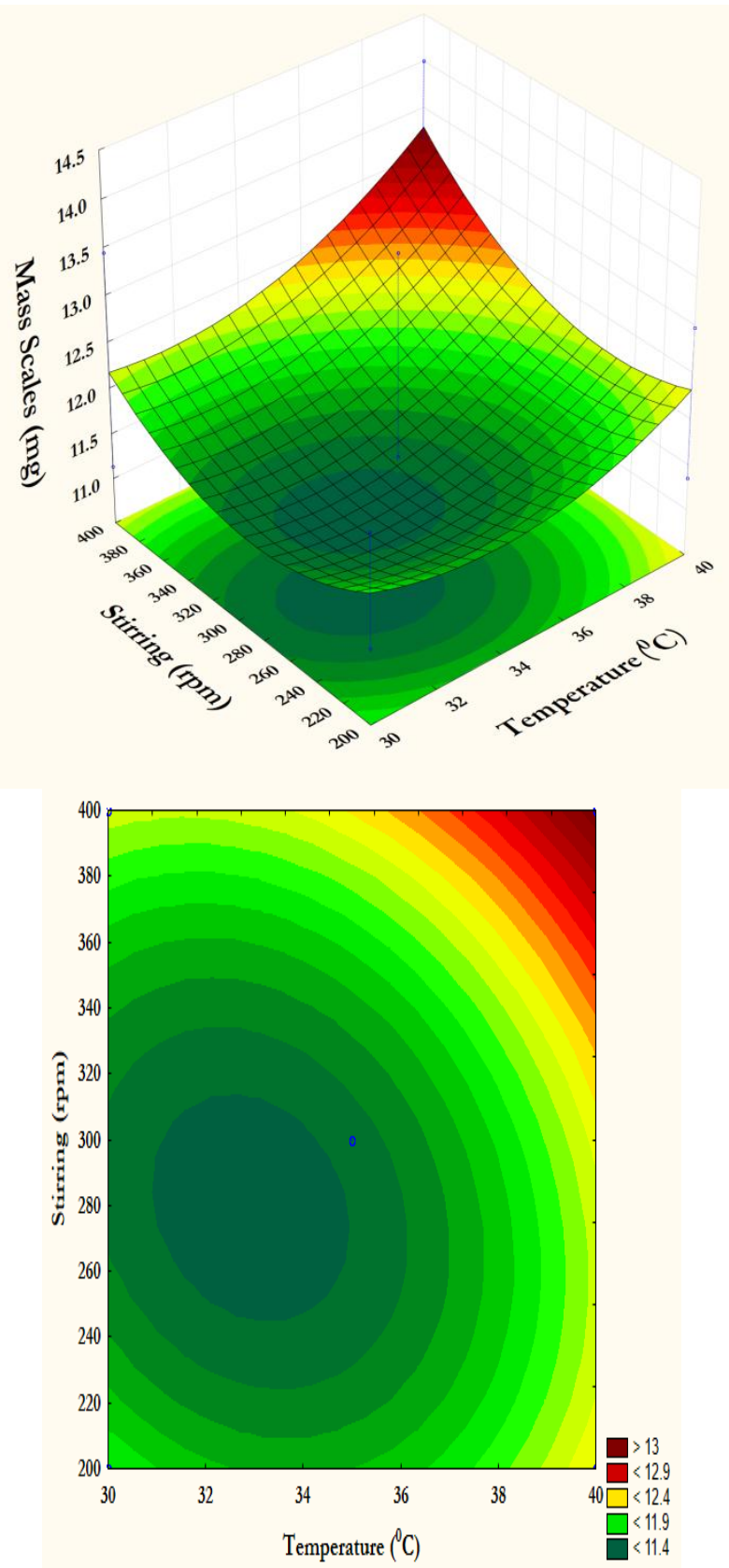

Fig. 4. Response Surface and Contour Plot for Interaction on Mass Crystal Production Between Temperature and Stirring Speed.

Further, the optimum mass scales was obtained by entering values into the equation, which include the optimum ratio of the mass response for variable optimization. Optimum mass scales are presented in Table 4.

TABLE IV. OPTIMUM MASS SCALES (MG).

\begin{tabular}{|l|l|c|}
\hline \multicolumn{1}{|c|}{ Factor } & Optimum State & $\begin{array}{c}\text { Optimum Mass Scales } \\
(\text { mg })\end{array}$ \\
\hline Temperature $\left({ }^{\circ} \mathrm{C}\right)$ & 32.07 & 10.432 \\
\hline $\begin{array}{l}\text { Maleic acid concentration } \\
(\mathrm{ppm})\end{array}$ & 19.68 & \\
\hline Stirring speed $(\mathrm{rpm})$ & 306.54 & \\
\hline
\end{tabular}

\section{Validation of the Predicted Value for the Optimal Variables.}

The optimum values of the process variables were then verified using the experimental data. The optimum yield of struvite was calculated using the each temperature (32.07 ppm), maleic acid Concentration (19.68 ppm) and stirring speed (306.54 rpm) and resulted in $10.432 \mathrm{mg}$ of the precipitated struvite [Table 4]. Additionally, the experimental result of the mass scale at these concentrations was $10.825 \mathrm{mg}$ [Table 5]. Here the calculated \% error for for the mass scale response was $3.75 \%$. This means for the estimated response of struvite production has an accuracy of $96.25 \%$.

TABLE V. OPTIMUM CONDITIONS AND THE PREDICTED AND EXPERIMENTAL VALUE OF RESPONSE AT THE OPTIMUM CONDITIONS.

\begin{tabular}{|l|l|l|l|l|}
\hline \multicolumn{1}{|c|}{ Optimum variables } & & $\begin{array}{c}\text { Optimum } \\
\text { Result }\end{array}$ & $\begin{array}{c}\text { Experimental } \\
\text { Result }\end{array}$ & $\begin{array}{c}\text { \% } \\
\text { Relative } \\
\text { error }\end{array}$ \\
\hline & & & Mass Scales & \\
\hline Temperature $\left({ }^{0} \mathrm{C}\right)$ & 32.07 & & & $3.75 \%$ \\
\hline $\begin{array}{l}\text { Maleic Acid } \\
\text { Concentration (ppm) }\end{array}$ & 19.68 & 10.432 & 10.825 & \\
\hline Stirring Speed (rpm) & 306.54 & & & \\
\hline
\end{tabular}

${ }^{\text {a. }}$ Relative error $(\%)=[($ Experimental result - Optimum result by SRM)/Experimental result $] \times 100 \%$.

\section{CONCLUSIONS}

SRM optimization of variable concentrations of heavy metals in the wastewater provided that the availability of Maleic acid concentration has a significant effect on the mass yield of struvite during precipitation. The optimum result of the mass response scale $(10.432 \mathrm{mg})$ was related to temperature (30 ppm), maleic acid Concentration (20 ppm) and stirring speed $(300 \mathrm{rpm})$ respectively. Accordingly, a good achievement of modeling and optimization of struvite precipitation was presented in this paper. The influence of selected parameters and thus model validation with insignificance parameters could be confirmed. Finally, an easy, simple, and cost effective method for wastewater treatment and precipitation of a valuable fertilizer product rich in phosphorous would likely to be implemented.

\section{ACKNOWLEDGEMENTS}

Ack to the Ministry of Research, Technology and Higher Education of the Republic of Indonesia which has finded this research through Doctoral Dissertation Research Grant with contract number 26 / UN63.8 / LT - Kontrak / II / 2018.

\section{REFERENCES}

[1] Doyle, J.D. and Parsons, S.A. Struvite formation, control and recovery. Water. Res. 36, 3925-3940. 2002.

[2] Capdeviellea. A, Sykorová. E, Biscans. B, Bélinea. F, Daumer. M-L. Optimization ofstruvite precipitation in synthetic biologically treated swine wastewater-Determination of the optimal process parameters, J. Hazard. Mater.. 244-245 ,357-369. 2013. 
[3] Mohajit, X., Bhattarai, K.K., Taiganides, E.P., Yap, B.C.. Struvite deposits in pipes and aerators, Biol. Wastes, 30, $133-147,1989$

[4] Doyle, J.D. Oldring, K. Churchley, J. Price, C. and Parsons, S.A.. Chemical control of struvite precipitation. J. Environ. Eng.- ASCE 129, 419-426, 2003.

[5] Booker, N. A., Priestley, A. J. and Fraser, I. H.. Struvite formation in wastewater treatment plants: Opportunities for nutrient recovery. Environ. Tech., 20, 777 - 782, 1999.

[6] Snoeyink, V. L. and Jenkins, D.. Water Chemistry, New York, John Wiley and Sons, 1980

[7] Shalaby, M.S. El-Rafie, S.h. Hamzaoui, A.H. M'nif, A.. Modelling and optimization of phosphate recovery from industrial wastewater and precipitation of solid fertilizer using experimental design methodology, Chem. \& Biochem. Eng., 29, 35 - 46, 2015.

[8] Burke. S, Heathwaite, L, and Preedy, N.. Transfer of phosphorus to surface waters; eutrophication. In: Phosphorus in Environmental Technologies, principles and applications, Valsami-Jones, E. (Ed), pp. 120-146, IWA Publishing, 2004

[9] Borgerding, J., Phosphate deposits in digestion system, J of the Water Pollut. Control Federation, 44, 813 - 819, 1972
[10] Mamais, D. Pitt, P.A. Cheng, Y.W. Loiacono, J. Jenkins, D. Determination of ferric chloride dose to control struvite precipitation in anaerobic sludge digesters, Water. Environ. Res., 66, 912 - 918, 1994

[11] Muryanto, S. Bayuseno, A.P.. Influence of $\mathrm{Cu}^{2+}$ and $\mathrm{Zn}^{2+}$ as additives on precipitation kinetics and morphology of struvite, Powder Tech.. 253, 602-607, 2014

[12] Rouff, A. A., Sorption of chromium with struvite during phosphorus recovery, Environ.l Sci. Technol., 46, 12493 - 12501, 2012.

[13] Peng, C., Chai, L-Y., Tang, C-J., Min, X-B., Ali, M., Y-X, Song., and Qi, W-M., Feasibility and enhancement of copper and ammonia removal from wastewater using struvite formation: a comparative research, J Chem Technol. Biotechnol., 92, 325 - 333, 2017.

[14] Muryanto. S, Bayuseno. A.P, Ma'mun. H, Usamah, M, Jotho.. Calcium carbonate scale formation in pipes: effect of flow rates, temperature, and malic acid as additives on the mass and morphology of the scale, Procedia Chem., 9, 69 - 76, 2014

[15] Rabizadeh, Taher. Caroline, L. Peacock and Liane, G. Benning.. Carboxylic acids: effective inhibitors for calcium sulfate precipitation. Mineral. Magazine 78(6), 1465-1472, 2014

[16] Rietveld, H.M.. A profile refinement method for nuclear and magnetic structures, J. Appl. Crystallogr., 2, 65-71, 1969. 